ELSEVIER

ORIGINAL ARTICLE

\title{
The risky body mass index ranges for significant hepatitis B viral load: A campus-based study
}

\author{
Chien-Hsieh Chiang ${ }^{a, b, e}$, Jin-Shin Lai ${ }^{c, e}$, Jin-Chuan Sheu ${ }^{\text {d,f }}$, \\ Lee-Lan Yen', Chun-Jen Liu ${ }^{d, f}$, Kuo-Chin Huang ${ }^{a, e, h, *}$
}

\author{
a Department of Family Medicine, National Taiwan University Hospital, Taipei, Taiwan \\ b Department of Community and Family Medicine, National Taiwan University Hospital Yun-Lin Branch, \\ Yun-Lin, Taiwan \\ c Department of Physical Medicine and Rehabilitation, National Taiwan University Hospital, Taipei, \\ Taiwan \\ d Department of Internal Medicine, National Taiwan University Hospital, Taipei, Taiwan \\ e Health Science and Wellness Center, National Taiwan University, Taipei, Taiwan \\ f Liver Disease Prevention and Treatment Research Foundation, Taipei, Taiwan \\ $\mathrm{g}$ Institute of Health Policy and Management, National Taiwan University, Taipei, Taiwan \\ h Graduate Institute of Clinical Medical Science, China Medical University, Taichung, Taiwan
}

Received 11 January 2011; received in revised form 18 April 2011; accepted 18 April 2011

KEYWORDS

HBV DNA;

Body mass index;

Insulin resistance;

Risk factor;

Taiwan

\begin{abstract}
Summary Significant hepatitis B viral load $(\geq 10,000$ copies $/ \mathrm{mL}$ ) was established to increase risk of advanced liver diseases. The aim of this study was to explore the metabolic risk factors for significant hepatitis B viral load. A campus-based cohort consisting of 146 participants of chronic hepatitis B virus (HBV) infection in Northern Taiwan was investigated in 2009. Clinical profiles including serum levels of deoxyribonucleic acid of hepatitis B virus (HBV DNA) were collected. Hepatitis B e antigen $(\mathrm{HBeAg})$ serostatus, high alanine aminotransferase level, body mass index (BMI) ranges, and insulin resistance were related to significant HBV DNA levels in univariate analysis. Compared to individuals with $\mathrm{BMI} 23-24.9 \mathrm{~kg} / \mathrm{m}^{2}$ in multivariate analysis, those with $\mathrm{BMI} \geq 25 \mathrm{~kg} / \mathrm{m}^{2}(\mathrm{OR}=3.86,95 \% \mathrm{Cl}=1.38-10.8, P=0.010)$ and those with $\mathrm{BMI}<23 \mathrm{~kg} / \mathrm{m}^{2}(\mathrm{OR}=4.47,95 \% \mathrm{Cl}=1.32-15.2, P=0.016)$ were at higher risk for significant HBV DNA levels. This phenomenon was also manifest in HBeAg seronegatives, who contributed to a majority of significant viral load in our study. Furthermore,
\end{abstract}

* Corresponding author at: Department of Family Medicine, National Taiwan University Hospital, 7, Chung Shan South Road, Taipei 100, Taiwan. Tel.: +8862 23123456x66081; fax: +886223118674.

E-mail addresses: jiansie@ntu.edu.tw (C.-H. Chiang), jslai@ntu.edu.tw (J.-S. Lai), sheuhcc@ntuh.gov.tw (J.-C. Sheu), leelan@ntu.edu.tw (L.-L. Yen), cjliu@ntu.edu.tw (C.-J. Liu), bretthuang@ntu.edu.tw (K.-C. Huang). 
insulin resistance and $\mathrm{BMI} \geq 25 \mathrm{~kg} / \mathrm{m}^{2}$ had positive additive effects on significant $\mathrm{HBV}$ DNA levels (adjusted $\mathrm{OR}=9.34,95 \% \mathrm{Cl}=1.74-50.3, P=0.009$ ). In conclusion, having certain $\mathrm{BMI}$ ranges $\left(\mathrm{BMI} \geq 25 \mathrm{~kg} / \mathrm{m}^{2}\right.$ or $\mathrm{BMI}<23 \mathrm{~kg} / \mathrm{m}^{2}$ ) could be a risk factor of significant HBV DNA levels.

(C) 2011 Asian Oceanian Association for the Study of Obesity. Published by Elsevier Ltd. All rights reserved.

\section{Introduction}

Chronic hepatitis B virus (HBV) infection is a challenging global health issue, especially in the Asia Pacific region. Although the universal vaccination program in Taiwan decreased the carrier rate of hepatitis B surface antigen ( $\mathrm{HBsAg}$ ) from $10 \%$ in 1984 to less than $1 \%$ in 2004 [1,2], the disease burden there was not yet eradicated. It contributes to more than 122 million USD of Taiwan medical cost for outpatient and inpatient care in 2007 (www.doh.gov.tw) [Statistical Annual Report of Medical Care 2007].

High levels of deoxyribonucleic acid of hepatitis $B$ virus (HBV DNA) lead to an increased risk of cirrhosis and hepatocellular carcinoma [3-5]. However, conventional medical interventions for HBV carriers with a large viral load are not always indicated based on current guidelines [6]. This population should be studied to identify convenient clinical predictors for developing a large viral load, and then to establish further preventive strategies.

Some animal models have shown that HBV gene expression is regulated similarly to key metabolic genes in hepatocytes, and thus HBV is believed to behave like a "metabolovirus" [7]. The prevalence of obesity and metabolic syndrome has been increasing in Taiwan in recent years [8-10]. The naturally acquired HBV infection of university freshmen resulted in a higher risk for developing metabolic syndrome compared to individuals having seroprotective titers from HBV vaccination [11]. Moreover, metabolic factors have been found to increase the risk of progression to late outcomes such as cirrhosis and hepatocellular carcinoma [12-14]. But few epidemiological studies examine the relationship between metabolic factors and the early outcome predictor - hepatitis B viral load [13]. Therefore, we tested the hypothesis that the presence of certain metabolic factors in chronic HBV-infected individuals is associated with significant HBV DNA levels in a campus-based study.

\section{Materials and methods}

\section{Participants}

Participants with chronic HBV infection (positive $\mathrm{HBsAg}$ serostatus for 6 months or longer) were recruited from the student, alumni, faculty and staff population of a university in northern Taiwan from August 1, 2009 to December 15, 2009. Only individuals aged 18 or older were included. Excluded were: (a) those who had been diagnosed with chronic liver diseases including chronic hepatitis $C$ virus infection, autoimmune hepatitis, Wilson disease, alcoholic liver diseases, drug-related hepatitis, decompensated liver diseases, cirrhosis, or malignant hepatic tumors; (b) those who had received liver transplantation or major operations involving the liver, except cholecystectomy; (c) men who consumed more than $30 \mathrm{~g}$, or women who consumed more than $20 \mathrm{~g}$, of alcohol per week; (d) women who were pregnant; (e) those who had medications for any type of chronic diseases except for hyperglycemia, elevated blood pressure, or dyslipidemia within 6 months. Written informed consents were obtained from all participants. Patients with alanine aminotransferase (ALT) levels exceeding twice the upper limit and HBV DNA levels more than 10,000 copies $/ \mathrm{mL}$ were referred to hepatologists for further evaluation and management. A total of 180 candidates registered in the Hepatitis B databank of National Taiwan University Health Center were invited to participate, and 165 were enrolled with an informed consent. They agreed to participate in questionnaire interview, health examination and blood collection for serological and biochemical assays at study entry. They also gave their consent for confirming their health and viral status through medical record review. Among them, 19 were excluded for negative serum $\mathrm{HBsAg}$ or positive serum antibody to hepatitis C virus. The study protocol was approved by the National Taiwan University Hospital Research Ethics Committee. 


\section{Anthropometric indices and laboratory measurements}

Body height and weight were measured using a single stadiometer and body mass index (BMI) was calculated. The participants were classified as normal or underweight (BMl $<23 \mathrm{~kg} / \mathrm{m}^{2}$ ), overweight (BMI $23-24.9 \mathrm{~kg} / \mathrm{m}^{2}$ ), or obese $\left(B M I \geq 25 \mathrm{~kg} / \mathrm{m}^{2}\right.$ ) according to the potential public health action points for Asian populations as recommended by World Health Organization [15]. Waist circumference (WC) was taken at the end of exhalation in the horizontal plane containing the point midway between the inferior margin of the lowest rib and the iliac crest. Central obesity was defined as $W C \geq 90 \mathrm{~cm}$ for men and $W C \geq 80 \mathrm{~cm}$ for women according to the criteria for metabolic syndrome currently used in Taiwan (www.bhp.doh.gov.tw). Blood pressure (BP) was measured with an electronic sphygmomanometer with the patient seated after resting for at least $10 \mathrm{~min}$. Elevated BP was defined as systolic BP $\geq 130 \mathrm{mmHg}$ or diastolic BP $\geq 85 \mathrm{mmHg}$ also based on the criteria for metabolic syndrome used in Taiwan.

Each participant received laboratory tests after fasting for at least $8 \mathrm{~h}$. Serological tests included serum $\mathrm{HBsAg}$, serum antibody to hepatitis $C$ virus, and hepatitis $B$ e antigen ( $\mathrm{HBeAg}$ ) by microparticle enzyme immunoassay (Abbott Laboratories, IL, USA). HBV DNA levels were measured by COBAS TaqMan real-time polymerase chain reaction assay (Roche Diagnostics, Basel, Switzerland), which detects an upper limit of $640,200,000$ copies $/ \mathrm{mL}$ and a lower limit of 35 copies $/ \mathrm{mL} \quad(1$ copies $/ \mathrm{mL}=0.1718 \mathrm{IU} / \mathrm{mL})$. A significant HBV DNA level was defined as 10,000 copies $/ \mathrm{mL}$ or more. A high ALT level, determined using the COBAS kinetic UV method (Roche Diagnostics, Basel, Switzerland), was defined as $41 \mathrm{IU} / \mathrm{L}$ or more for men and $31 \mathrm{lU} / \mathrm{L}$ or more for women. A high fasting glucose level, determined using the hexokinase method, was defined as $100 \mathrm{mg} / \mathrm{dL}$ or more $(1 \mathrm{mg} / \mathrm{dL}=0.0555 \mathrm{mmol} / \mathrm{L})$. Serum fasting insulin levels were measured using the COBAS electrochemiluminescence immunoassay (Roche Diagnostics, Basel, Switzerland) $(1 \mu \mathrm{lU} / \mathrm{mL}=6.945 \mathrm{pmol} / \mathrm{L})$. Insulin resistance scores were determined by the homeostasis model assessment of insulin resistance (HOMA-IR), as calculated by the following formula: HOMA-IR score $=$ fasting insulin $(\mu \mathrm{lU} / \mathrm{mL}) \times$ fasting glucose $(\mathrm{mg} / \mathrm{dL}) / 405$ [16,17]. Participants were categorized as insulin resistant if the HOMA-IR was 2.5 or more [18]. A low high-density lipoprotein cholesterol (HDL-C) level, determined by the homogeneous enzymatic colorimetric assay, was defined as $\mathrm{HDL}-\mathrm{C}<40 \mathrm{mg} / \mathrm{dL}$ for men and $<50 \mathrm{mg} / \mathrm{dL}$ for women $(1 \mathrm{mg} / \mathrm{dL}=0.0259 \mathrm{mmol} / \mathrm{L})$. A high low-density lipoprotein cholesterol (LDL-C) level, using the same method, was defined as $\mathrm{LDL}-\mathrm{C} \geq 130 \mathrm{mg} / \mathrm{dL} \quad(1 \mathrm{mg} / \mathrm{dL}=0.0259 \mathrm{mmol} / \mathrm{L})$. A high triglycerides level was defined as triglycerides $\geq 150 \mathrm{mg} / \mathrm{dL}(1 \mathrm{mg} / \mathrm{dL}=0.0113 \mathrm{mmol} / \mathrm{L})$ and a high sensitive $\mathrm{C}$-reactive protein (hs-CRP) level was defined as $h s-C R P \geq 0.3 \mathrm{mg} / \mathrm{dL}(1 \mathrm{mg} / \mathrm{dL}=10 \mathrm{mg} / \mathrm{L})$.

\section{Statistical analysis}

For descriptive analyses values were presented as number (percent) or mean \pm standard deviation (SD). For univariate analyses the chi-square test or Fisher exact test was applied to categorical data. Continuous variables were compared using the two-sample Student's $t$ test. Absolute HBV DNA levels were compared using the Mann-Whitney-Wilcoxon rank-sum test. Multiple logistic regression analyses were used to examine whether metabolic factors were independently or jointly associated with significant HBV DNA level after adjustment for potential confounding factors. Stepwise subgroup analyses were also performed for $\mathrm{HBeAg}$ seronegatives and also for HBeAg seronegatives with normal ALT levels. The odds ratios (ORs) and 95\% confidence intervals (Cls) were derived to assess the magnitude of the association between various predictors of high serum HBV DNA levels. Significance levels were determined by two-tailed tests $(P<0.05)$. All the statistical analyses were performed with SAS software version 9.1.3 (SAS Institute Inc., Cary, NC, USA). The post hoc statistical power was calculated by the online OpenEpi software version 2.3 (www.OpenEpi.com).

\section{Results}

\section{Clinical characteristics of participants}

Among the 146 participants in this study were 67 (45.89\%) with HBV DNA levels less than 10,000 copies $/ \mathrm{mL}$ and 11 (7.53\%) with levels lower than the detectable limit $(<35$ copies $/ \mathrm{mL})$. As shown in Table 1, there were 79 participants (54.11\%) with HBV DNA levels of 10,000 copies $/ \mathrm{mL}$ or greater (significant HBV DNA levels) and 23 $(15.75 \%)$ with levels greater than the detectable limit $(\geq 640,200,000$ copies $/ \mathrm{mL})$. The majority of participants were male $(n=114,78.08 \%)$, younger than 40 years $(n=120,82.19 \%)$, without high ALT levels $(n=101,69.18 \%)$, HBeAg seronegative 
Table 1 Clinical profiles of participants by the presence of significant HBV DNA levels.

\begin{tabular}{|c|c|c|c|}
\hline Factor & $\begin{array}{l}\text { Non-significant HBV } \\
\text { DNA level }(n=67)\end{array}$ & $\begin{array}{l}\text { Significant HBV DNA } \\
\text { level }(n=79)\end{array}$ & $P$-value \\
\hline Age (years), mean $\pm S D$ & $32.33 \pm 6.96$ & $32.85 \pm 9.24$ & 0.699 \\
\hline Male, $n(\%)$ & $54(80.60)$ & $60(75.95)$ & 0.499 \\
\hline HBeAg seronegative, $n(\%)$ & $65(97.01)$ & $44(55.70)$ & $<0.0001$ \\
\hline High ALT level, $n(\%)$ & $13(19.40)$ & $32(40.51)$ & 0.006 \\
\hline $\mathrm{BMI}\left(\mathrm{kg} / \mathrm{m}^{2}\right)$, mean $\pm \mathrm{SD}$ & $24.91 \pm 3.25$ & $25.38 \pm 3.99$ & 0.441 \\
\hline $\mathrm{BMI}<23, n(\%)$ & $13(19.40)$ & $23(29.11)$ & \\
\hline BMI $23-24.9 \mathrm{Kg} / \mathrm{m}^{2}$ & $28(41.79)$ & $14(17.72)$ & 0.006 \\
\hline $\mathrm{BMI} \geq 25, n(\%)$ & $26(38.81)$ & $42(53.16)$ & \\
\hline $\mathrm{WC}(\mathrm{cm})$, mean $\pm S D$ & $87.16 \pm 8.90$ & $87.94 \pm 10.62$ & 0.632 \\
\hline Central obesity, $n(\%)$ & $34(50.75)$ & $39(49.37)$ & 0.868 \\
\hline Elevated BP, $n(\%)$ & $19(28.36)$ & $26(32.91)$ & 0.554 \\
\hline Glucose $A C(\mathrm{mg} / \mathrm{dL})$, mean $\pm S D$ & $74.16 \pm 9.35$ & $76.65 \pm 8.61$ & 0.098 \\
\hline Insulin $(\mu \mathrm{IU} / \mathrm{mL})$, mean \pm SD & $7.69 \pm 4.09$ & $8.89 \pm 0.57$ & 0.120 \\
\hline $\mathrm{HOMA}-\mathrm{IR}$, mean $\pm \mathrm{SD}$ & $1.42 \pm 0.76$ & $1.70 \pm 0.99$ & 0.053 \\
\hline Insulin resistance, $n(\%)$ & $5(7.46)$ & $16(20.25)$ & 0.017 \\
\hline Low HDL-C level, $n(\%)$ & $8(11.94)$ & 15 (18.99) & 0.244 \\
\hline High LDL-C level, $n(\%)$ & $22(32.84)$ & $30(37.97)$ & 0.518 \\
\hline High triglycerides level, $n(\%)$ & $8(11.94)$ & 15 (18.99) & 0.244 \\
\hline High hs-CRP level, $n(\%)$ & $7(10.45)$ & 12 (15.19) & 0.396 \\
\hline
\end{tabular}

ALT, alanine aminotransferase; BMI, body mass index; BP, blood pressure; Glucose AC, overnight fasting glucose; HBeAg, hepatitis B e antigen; HBV DNA, deoxyribonucleic acid of hepatitis B virus (significant $\geq 10^{4}$ copies $/ \mathrm{mL}$; non-significant, $<10^{4} \mathrm{copies} / \mathrm{mL}$ ); HDL-C, high-density lipoprotein cholesterol; HOMA-IR, homeostasis model assessment of insulin resistance; Hs-CRP, high sensitivity $C$ reactive protein; LDL-C, low-density lipoprotein cholesterol; WC, waist circumference.

Conversion factors to SI units: glucose AC $(1 \mathrm{mg} / \mathrm{dL}=0.0555 \mathrm{mmol} / \mathrm{L})$, HBV DNA $(1 \mathrm{copies} / \mathrm{mL}=0.1718 \mathrm{IU} / \mathrm{mL})$, insulin $(1 \mu \mathrm{lU} / \mathrm{mL}=6.945 \mathrm{pmol} / \mathrm{L})$.

$(n=109,74.66 \%)$, and obese $(n=68,46.58 \%)$. Participants with significant HBV DNA levels were more likely to have positive HBeAg serostatus $(P<0.0001)$ and high ALT levels $(P=0.006)$.

\section{Metabolic factors and significant HBV DNA levels}

Participants with significant HBV DNA levels were less likely to have BMI $23-24.9 \mathrm{~kg} / \mathrm{m}^{2} \quad(P=0.006)$ but more likely to have insulin resistance $(P=0.017)$ (Table 1). The post hoc statistical power was $90.11 \%$ based on the presence of significant HBV DNA levels across two $B M I$ groups (BMI $23-24.9 \mathrm{~kg} / \mathrm{m}^{2}$ vs. $\left(B M I<23 \mathrm{~kg} / \mathrm{m}^{2}\right.$ or $\left.B M I \geq 25 \mathrm{~kg} / \mathrm{m}^{2}\right)$, i.e., overweight vs. non-overweight). The median value of HBV DNA level of individuals with BMI $23-24.9 \mathrm{~kg} / \mathrm{m}^{2}$ was lower than that of individuals with $B M I<23 \mathrm{~kg} / \mathrm{m}^{2}$ ( 3306.0 vs. 38779.0 copies $/ \mathrm{mL}, P=0.171)$ and that of individuals with $\mathrm{BMI} \geq 25 \mathrm{~kg} / \mathrm{m}^{2}(3306.0$ vs. 24833.5 copies $/ \mathrm{mL}, P=0.027$ ). Using multivariate logistic regression analyses adjusted for age, gender, HBeAg serostatus, and high ALT level, the ORs of $\mathrm{BMI}$ ranges and insulin resistance for significant HBV DNA levels are shown in Table 2. Those with $\mathrm{BMI} \geq 25 \mathrm{~kg} / \mathrm{m}^{2}(\mathrm{OR}=3.86,95 \% \mathrm{Cl}=1.38-10.8$,
$P=0.010)$ and those with $\mathrm{BMl}<23 \mathrm{~kg} / \mathrm{m}^{2}(\mathrm{OR}=4.47$, 95\% $\mathrm{Cl}=1.32-15.2, \quad P=0.016)$, were at higher risk for significant HBV DNA levels as compared to the those with BMI $23-24.9 \mathrm{~kg} / \mathrm{m}^{2}$. In addition, participants with positive $\mathrm{HBeAg}$ serostatus were at a significantly higher risk for significant HBV DNA levels $(\mathrm{OR}=41.8,95 \% \mathrm{Cl}=8.15-214.0$, $P<0.0001)$ than those with negative HBeAg serostatus.

Among participants with $\mathrm{HBeAg}$ seronegative status, subjects with $\mathrm{BMI} \geq 25 \mathrm{~kg} / \mathrm{m}^{2}$ (OR $=3.76$, $95 \% \mathrm{Cl}=1.30-10.9, P=0.015)$ and subjects with BMI $<23 \mathrm{~kg} / \mathrm{m}^{2} \quad(\mathrm{OR}=5.26,95 \% \quad \mathrm{Cl}=1.59-17.4$, $P=0.007$ ), were at increased risk for significant HBV DNA levels as compared to subjects with BMI $23-24.9 \mathrm{~kg} / \mathrm{m}^{2}$ after adjusting for age, gender, high ALT level, and insulin resistance (Table 3 ). In the subgroup analysis of $\mathrm{HBeAg}$ seronegatives with normal ALT levels, the non-overweight participants $\quad(\mathrm{OR}=3.97, \quad 95 \% \quad \mathrm{Cl}=1.29-12.2$, $P=0.016)$, including the obese $(\mathrm{OR}=3.96,95 \%$ $\mathrm{Cl}=1.18-13.3, \quad P=0.026)$ and the normal or underweight $\quad(\mathrm{OR}=3.70, \quad 95 \% \quad \mathrm{Cl}=1.02-13.4$, $P=0.046$ ), also were at increased risk for significant HBV DNA levels than their overweight counterparts. 
Table 2 Multiple logistic regression analysis of factors for significant HBV DNA levels $(n=146)$.

\begin{tabular}{|c|c|c|}
\hline Factor & OR $(95 \% \mathrm{Cl})$ & $P$-value \\
\hline \multicolumn{3}{|l|}{ HBeAg serostatus } \\
\hline Positive vs. negative & $41.8(8.15-214)$. & $<0.0001$ \\
\hline High ALT level (yes vs. no) & $1.70(0.66-4.38)$ & 0.272 \\
\hline \multicolumn{3}{|l|}{ BMI $\left(\mathrm{kg} / \mathrm{m}^{2}\right)$} \\
\hline$<23$ vs. $\mathrm{BMI} 23-24.9 \mathrm{Kg} / \mathrm{m}^{2}$ & $4.47(1.32-15.2)$ & 0.016 \\
\hline$\geq 25$ vs. BMI $23-24.9 \mathrm{Kg} / \mathrm{m}^{2}$ & $3.86(1.38-10.8)$ & 0.010 \\
\hline Insulin resistance (yes vs. no) & $1.88(0.52-6.83)$ & 0.337 \\
\hline
\end{tabular}

Model: age, gender (male vs. female), HBeAg serostatus (positive vs. negative), high ALT level (yes vs. no), BMI ranges, and insulin resistance (yes vs. no).

ALT, alanine aminotransferase; BMI, body mass index; HBeAg, hepatitis B e antigen; HBV DNA, deoxyribonucleic acid of hepatitis $B$ virus (significant, $\geq 10^{4}$ copies $/ \mathrm{mL}$ ) $(1$ copies $/ \mathrm{mL}=0.1718 \mathrm{IU} / \mathrm{mL})$.

Table 3 Multiple logistic regression analysis of BMI ranges for significant HBV DNA levels in HBeAg seronegatives.

\begin{tabular}{|c|c|c|c|c|}
\hline \multirow[t]{2}{*}{$\mathrm{BMI}\left(\mathrm{kg} / \mathrm{m}^{2}\right)$} & \multicolumn{2}{|c|}{$\begin{array}{l}\text { HBeAg seronegatives } \\
(n=109)^{\mathrm{a}}\end{array}$} & \multicolumn{2}{|c|}{$\begin{array}{l}\text { HBeAg seronegatives with } \\
\text { normal ALT levels }(n=82)^{\mathrm{b}}\end{array}$} \\
\hline & OR $(95 \% \mathrm{Cl})$ & $P$-value & OR $(95 \% \mathrm{Cl})$ & $P$-value \\
\hline$<23$ vs. BMI $23-24.9 \mathrm{Kg} / \mathrm{m}^{2}$ & $5.26(1.59-17.4)$ & 0.007 & $3.70(1.02-13.4)$ & 0.046 \\
\hline$\geq 25$ vs. BMI $23-24.9 \mathrm{Kg} / \mathrm{m}^{2}$ & $3.76(1.30-10.9)$ & 0.015 & $3.96(1.18-13.3)$ & 0.026 \\
\hline
\end{tabular}

ALT, alanine aminotransferase; BMI, body mass index; HBeAg, hepatitis B e antigen; HBV DNA, deoxyribonucleic acid of hepatitis $B$ virus (significant, $\geq 10^{4}$ copies $/ \mathrm{mL}$ ) $(1$ copies $/ \mathrm{mL}=0.1718 \mathrm{IU} / \mathrm{mL})$.

a Model: age, gender (male vs. female), high ALT level (yes vs. no), BMI ranges, and insulin resistance (yes vs. no).

b Model: age, gender (male vs. female), BMI ranges, and insulin resistance (yes vs. no).

Interaction between BMI ranges and insulin resistance is shown in Table 4. As compared to overweight individuals without insulin resistance, the $O R$ of obesity without insulin resistance for significant HBV DNA levels was 3.90 (95\% $\mathrm{Cl}=1.30-11.7, \quad P=0.015)$ after adjustment for age, gender, HBeAg serostatus, and high ALT level. The combination of insulin resistance and obesity further increased the adjusted risk for significant HBV DNA levels to 9.34 (95\% $\mathrm{Cl}=1.74-50.3, P=0.009$ ). Normal or underweight participants without insulin resistance still had a higher adjusted risk for significant HBV DNA levels $(\mathrm{OR}=4.98,95 \% \mathrm{Cl}=1.42-17.5, \quad P=0.012)$ than overweight individuals without insulin resistance.

Table 4 Interaction between BMI ranges and insulin resistance on significant HBV DNA levels $(n=146)$.

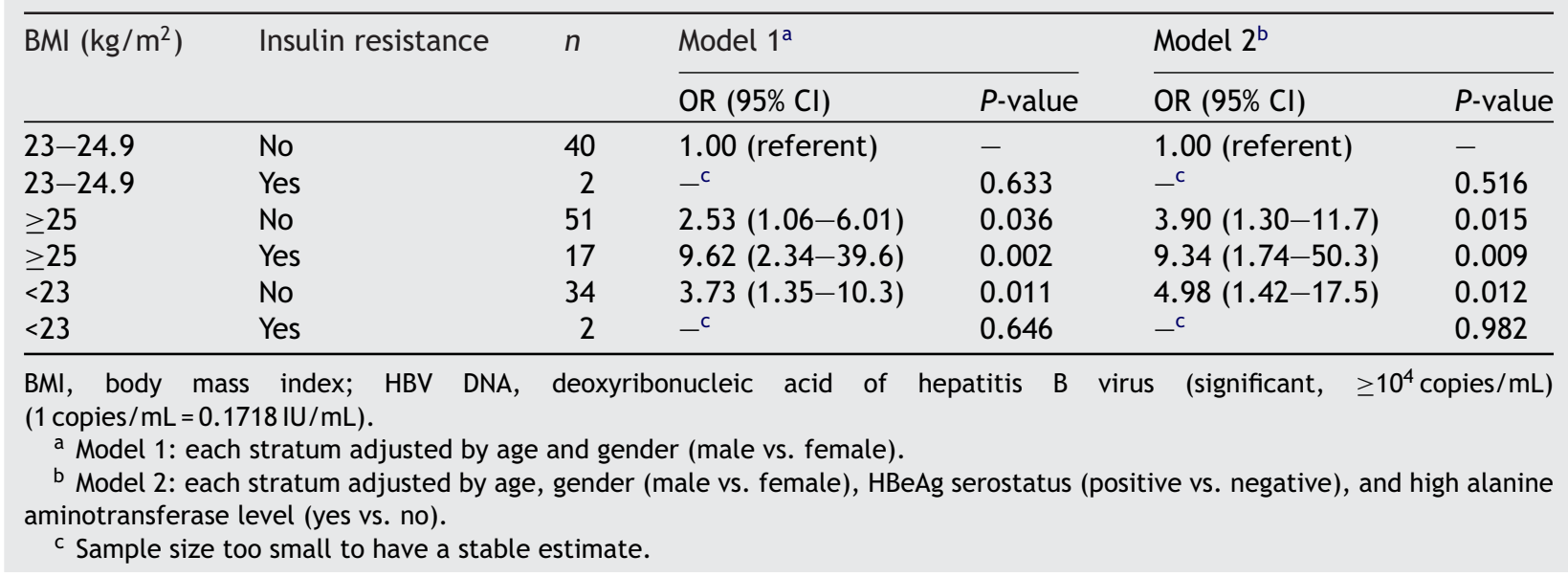




\section{Discussion}

This research pioneered to investigate the relationship between metabolic factors and significant hepatitis $B$ viral load in a campus-based cohort. Certain $B M I$ ranges $\left(B M I \geq 25 \mathrm{~kg} / \mathrm{m}^{2}\right.$ or $\mathrm{BMl}<23 \mathrm{~kg} / \mathrm{m}^{2}$ ) were positively associated with significant HBV DNA levels. Furthermore, insulin resistance and obesity had additive effects on significant hepatitis B viral load.

Insulin has been known to suppress HBV gene expression in cultured human liver cells [19]. Non-diabetic obese people tend to have subclinical insulin resistance $[20,21]$, and the subsequent attenuated inhibitory effects of insulin on HBV gene replication may partially explain our findings that obesity increased the risk of significant HBV DNA levels. In addition, similar factors activate the key gluconeogenic gene phosphoenolpyruvate carboxykinase and the HBV pre-core/core promoters [22]. Obese individuals might diet intentionally and therefore be exposed to starvation more frequently than their normal-weight counterparts, and thus the gluconeogenic cascade with consequent viral replication would be co-activated more often. Some adipokines are known to influence endogenous hepatic glucose metabolism [23]. For example, resistin increases hepatic glucose production [24], whereas adiponectin suppresses it [25]. In obese patients, high resistin and low adiponectin levels may contribute to increased hepatic glucose production, thereby possibly accelerating HBV gene replication.

Levels of circulating male sex hormones such as androgen are inversely associated with BMI $[26,27]$, components of the metabolic syndrome [28], and risk for type 2 diabetes [29,30]. Besides, a recent animal model demonstrated that higher androgen can increase HBV viral titers through direct binding to the androgen-responsive element sites [31,32]. These findings taken together might explain why individuals with $\mathrm{BMI}<23 \mathrm{~kg} / \mathrm{m}^{2}$ were at a higher risk of significant HBV DNA levels than those with BMl $23-24.9 \mathrm{~kg} / \mathrm{m}^{2}$. In other words, chronic HBV-infected individuals with low BMI would have high androgen levels and subsequent significant HBV viral load. However, other mechanisms regarding insulin, gluconeogenic cascade and adipokines, as described in the previous paragraph, predominate in those with $\mathrm{BMI}$ $\geq 25 \mathrm{~kg} / \mathrm{m}^{2}$.

Although insulin resistance has been associated with an increased risk for cirrhosis in patients with chronic HBV infection, it has not previously been associated with hepatitis B viral load [33]. Our results revealed that the individuals being both obese and insulin resistant were at about 9-fold adjusted risk for significant HBV DNA levels compared to those being overweight and not insulin resistant. However, there was no significant additive interaction from insulin resistance in normal or underweight participants. The underlying role of insulin resistance on hepatitis $B$ viral load in different BMI ranges warrants further research.

Unlike the Risk Evaluation of Viral Load Elevation and Associated Liver Disease/Cancer-HBV study $[5,13]$, no significant association of age and gender with HBV DNA levels was noted in the present study. That could be explained by the fact that this campus-based study population was younger $(32.6 \pm 8.6$ years vs. $45.9 \pm 9.8$ years) and predominantly male $(78.1 \%$ vs. $59.3 \%)$. Previous studies have reported that $\mathrm{HBeAg}$ seroconversion may not be complete in younger populations $[6,34,35]$. However, about $75 \%$ of our participants were $\mathrm{HBeAg}$ seronegatives, and $55.7 \%$ with significant HBV DNA levels were indeed $\mathrm{HBeAg}$ seronegatives. For these participants who are younger and deemed healthy, $\mathrm{HBeAg}$ seroconversion is actually followed by the phase of "HBeAg-negative chronic hepatitis B'" [36]. Careful assessments and individualized preventive acts should be advocated.

There are several limitations. First, this study is cross-sectional by design and so causal inference cannot be established. This cohort will be followed to look for time-dependent discrepancies between BMI ranges and serum viral load. Second, the participants volunteered rather than being randomly selected and thus the external validity was confined. Third, we did not recruit any diabetic participants. The effect of hyperglycemia on HBV DNA levels was not examined. However, we expect that the effect of BMI ranges on hepatitis $B$ viral load would be less confounded by hyperglycemia. In addition, determining the optimal BMI ranges for chronic HBV-infected individuals to have minimal viral load for all ethnic groups will be another challenge for future investigation.

\section{Conclusion}

A campus-based cohort of chronic HBV infection was investigated. We demonstrated that certain BMI ranges (BMI $\geq 25 \mathrm{~kg} / \mathrm{m}^{2}$ or $\mathrm{BMl}<23 \mathrm{~kg} / \mathrm{m}^{2}$ ) were positively associated with significant $\mathrm{HBV}$ DNA levels, whether in all participants or $\mathrm{HBeAg}$ seronegatives. Insulin resistance further had additive effects to obesity on significant hepatitis B viral 
load. Future research should be targeted more at the basic mechanism and the preventive strategies.

\section{Conflict of interest statement}

The authors declare no conflicts of interest.

\section{Acknowledgements}

This study was fully sponsored by the Research Fund of National Taiwan University (NTU 98R0537-01). We thank Shu-Wen Chang, Lucy Sin-Ni Lin and YuMin Lai at the Health Science and Wellness Center of National Taiwan University for their efforts in the data collection.

\section{References}

[1] Ni YH, Huang LM, Chang MH, Yen CJ, Lu CY, You SL, et al. Two decades of universal hepatitis $B$ vaccination in Taiwan: impact and implication for future strategies. Gastroenterology 2007;132:1287-93.

[2] Chien YC, Jan CF, Kuo HS, Chen CJ. Nationwide hepatitis B vaccination program in Taiwan: effectiveness in the 20 years after it was launched. Epidemiol Rev 2006;28:126-35.

[3] Chen CJ, Yang HI, Su J, Jen CL, You SL, Lu SN, et al. Risk of hepatocellular carcinoma across a biological gradient of serum hepatitis B virus DNA level. JAMA 2006;295:65-73.

[4] Iloeje UH, Yang HI, Su J, Jen CL, You SL, Chen CJ. Predicting cirrhosis risk based on the level of circulating hepatitis $B$ viral load. Gastroenterology 2006;130:678-86.

[5] Chen CJ, Yang HI, Iloeje UH. Hepatitis B virus DNA levels and outcomes in chronic hepatitis B. Hepatology 2009;49:S72-84.

[6] Liaw YF, Chu CM. Hepatitis B virus infection. Lancet 2009;373:582-92.

[7] Shlomai A, Shaul Y. The "metabolovirus" model of hepatitis $B$ virus suggests nutritional therapy as an effective anti-viral weapon. Med Hypotheses 2008;71:53-7.

[8] Lin YC, Yen LL, Chen SY, Kao MD, Tzeng MS, Huang PC, et al. Prevalence of overweight and obesity and its associated factors: findings from National Nutrition and Health Survey in Taiwan, 1993-1996. Prev Med 2003;37:233-41.

[9] Chu NF. Prevalence of obesity in Taiwan. Obes Rev 2005;6:271-4

[10] Huang KC. Obesity and its related diseases in Taiwan. Obes Rev 2008;9(Suppl. 1):32-4.

[11] Yen SL, Chiu TY, Lin YC, Lee YC, Lee LT, Huang KC. Obesity and hepatitis $B$ infection are associated with increased risk of metabolic syndrome in university freshmen. Int $\mathrm{J}$ Obes (Lond) 2008;32:474-80.

[12] Wong GL, Wong VW, Choi PC, Chan AW, Chim AM, Yiu KK, et al. Metabolic syndrome increases the risk of liver cirrhosis in chronic hepatitis B. Gut 2009;58:111-7.

[13] Chen CL, Yang HI, Yang WS, Liu CJ, Chen PJ, You SL, et al. Metabolic factors and risk of hepatocellular carcinoma by chronic hepatitis B/C infection: a follow-up study in Taiwan. Gastroenterology 2008;135:111-21.
[14] Inoue $M$, Kurahashi $N$, Iwasaki $M$, Tanaka $Y$, Mizokami $M$, Noda $M$, et al. Metabolic factors and subsequent risk of hepatocellular carcinoma by hepatitis virus infection status: $a$ large-scale population-based cohort study of Japanese men and women (JPHC Study Cohort II). Cancer Causes Control 2009;20:741-50.

[15] WHO Expert Consultation. Appropriate body-mass index for Asian populations and its implications for policy and intervention strategies. Lancet 2004;363:157-63.

[16] Matthews DR, Hosker JP, Rudenski AS, Naylor BA, Treacher DF, Turner RC. Homeostasis model assessment: insulin resistance and beta-cell function from fasting plasma glucose and insulin concentrations in man. Diabetologia 1985;28:412-9.

[17] Kumar M, Choudhury A, Manglik N, Hissar S, Rastogi A, Sakhuja $\mathrm{P}$, et al. Insulin resistance in chronic hepatitis B virus infection. Am J Gastroenterol 2009;104:7682.

[18] Chu CJ, Hung TH, Hwang SJ, Wang YJ, Yang CF, Lin HC, et al. Association of insulin resistance with hepatic steatosis and progression of fibrosis in Chinese patients with chronic hepatitis C. Hepatogastroenterology 2008;55:2157-61.

[19] Chen MF, Lin HM, Chou CK. Insulin dominantly suppresses hepatitis $B$ virus gene expression in cultured human hepatoma cells. J Biomed Sci 1997;4:295-9.

[20] McLaughlin T, Allison G, Abbasi F, Lamendola C, Reaven G. Prevalence of insulin resistance and associated cardiovascular disease risk factors among normal weight, overweight, and obese individuals. Metabolism 2004;53:495-9.

[21] Ohnishi H, Saitoh S, Takagi S, Ohata J, Takeuchi H, Isobe T, et al. Incidence of insulin resistance in obese subjects in a rural Japanese population: the Tanno and Sobetsu study. Diabetes Obes Metab 2005;7:83-7.

[22] Shlomai A, Shaul Y. The metabolic activator FOX01 binds hepatitis $B$ virus DNA and activates its transcription. Biochem Biophys Res Commun 2009;381:544-8.

[23] Marra F, Bertolani C. Adipokines in liver diseases. Hepatology 2009;50:957-69.

[24] Banerjee RR, Rangwala SM, Shapiro JS, Rich AS, Rhoades B, Qi Y, et al. Regulation of fasted blood glucose by resistin. Science 2004;303:1195-8.

[25] Andreelli F, Foretz M, Knauf C, Cani PD, Perrin C, Iglesias $M A$, et al. Liver adenosine monophosphate-activated kinase-alpha2 catalytic subunit is a key target for the control of hepatic glucose production by adiponectin and leptin but not insulin. Endocrinology 2006;147:2432-41.

[26] Yeap BB, Chubb SA, Hyde Z, Jamrozik K, Hankey GJ, Flicker $\mathrm{L}$, et al. Lower serum testosterone is independently associated with insulin resistance in non-diabetic older men: the Health In Men Study. Eur J Endocrinol 2009;161:591-8.

[27] Traish AM, Feeley RJ, Guay A. Mechanisms of obesity and related pathologies: androgen deficiency and endothelial dysfunction may be the link between obesity and erectile dysfunction. FEBS J 2009;276:5755-67.

[28] Kupelian V, Hayes FJ, Link CL, Rosen R, McKinlay JB. Inverse association of testosterone and the metabolic syndrome in men is consistent across race and ethnic groups. J Clin Endocrinol Metab 2008;93:3403-10.

[29] Ding EL, Song Y, Malik VS, Liu S. Sex differences of endogenous sex hormones and risk of type 2 diabetes: a systematic review and meta-analysis. JAMA 2006;295:1288-99.

[30] Ding EL, Song Y, Manson JE, Hunter DJ, Lee CC, Rifai N, et al. Sex hormone-binding globulin and risk of type 2 diabetes in women and men. New Engl J Med 2009;361:1152-63.

[31] Yang WJ, Chang CJ, Yeh SH, Lin WH, Wang SH, Tsai TF, et al. Hepatitis $B$ virus $X$ protein enhances the transcriptional activity of the androgen receptor through c-Src and 
glycogen synthase kinase-3beta kinase pathways. Hepatology 2009;49:1515-24.

[32] Wang SH, Yeh SH, Lin WH, Wang HY, Chen DS, Chen PJ. Identification of androgen response elements in the enhancer I of hepatitis B virus: a mechanism for sex disparity in chronic hepatitis B. Hepatology 2009;50:1392-402.

[33] Wong VW, Wong GL, Yu J, Choi PC, Chan AW, Chan HY, et al. Interaction of adipokines and hepatitis $B$ virus on histological liver injury in the Chinese. Am J Gastroenterol 2009;105:132-8.
[34] Chu CM, Hung SJ, Lin J, Tai DI, Liaw YF. Natural history of hepatitis $\mathrm{B}$ e antigen to antibody seroconversion in patients with normal serum aminotransferase levels. Am J Med 2004;116:829-34.

[35] Ni YH. Natural history of hepatitis B virus infection: pediatric perspective. J Gastroenterol 2011;46:1-8.

[36] Liver EAFTSOT. EASL Clinical Practice Guidelines: management of chronic hepatitis. Brit J Hepatol 2009;50: 227-42.

Available online at www.sciencedirect.com

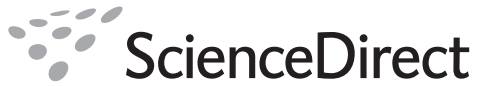

